\title{
From the Gold Clause Cases to the Gold Commission: A Half Century of American Monetary Law
}

\author{
Kenneth W. Dam†
}

Half a century ago, Franklin Roosevelt, in one of his first official acts, took the United States off the gold standard. That was the most lasting effect of the March 1933 Bank Holiday and its accompanying proclamations and legislation. ${ }^{1}$ This reversal of more than fifty years' resolute adherence to the gold standard was all the more remarkable because Roosevelt as candidate had excoriated Herbert Hoover's warning that the United States was close to going off gold as "a libel on the credit of the United States." Roosevelt declared that "no responsible government would have sold to the country securities payable in gold if it knew that the promise-yes, the covenant-embodied in these securities was as dubious as the President of the United States claims it was."2

In 1980 American voters, again dissatisfied with an economy that was reducing the standard of living of the American worker, ${ }^{3}$

$\dagger$ Deputy Secretary of State of the United States and Harold J. and Marion F. Green Professor of International Legal Studies, University of Chicago (on leave for government service). Mr. Dam completed work on the manuscript of this article before assuming his government position in September 1982. In any case the opinions expressed are solely his own.

${ }^{1}$ Debate exists as to the precise date on which the United States can be said to have left the gold standard. In April 1933 Roosevelt told the Secretary of the Treasury that he had taken the country off the gold standard, to which the Secretary replied, "What? Again?" R. Moley, The First New Deal 298 (1966). See also D. Acheson, Morning and Noon 166-67 (1965). The President exploited the ambiguity of the term, see infra text accompanying note 36, and in his first press conference two days after the March 6 ban on the export of gold enumerated possible criteria by which to judge adherence to the gold standard, some of which still obtained in the United States. 2 The Public Papers aND ADDResses of Frankin D. Roosevelt 33-35 (1938) [hereinafter cited as FDR PAPERs]. Nor did he reject the gold standard out of hand, stating on April 19,1933, "one of the things we hope to do is to get the world as a whole back on some form of gold standard." Id. at 140.

' N.Y. Times, Nov. 5, 1932, § 1, at 10, col. 2; see also L. Chamberdain, The President, Congress and Legislation 337 (1967); Garis, The Gold Clause, 165 Annals 219 (1933).

s Real wages, which had risen steadily between 1948 and 1972 (with the exception of a slight decline in 1958), declined between 1973 and November 1980, although nominal wages continued to rise. In the latter period, real average weekly earnings in selected private nonagricultural industries fell in 1967 dollars from $\$ 109$ to $\$ 95$; in current dollars they rose from $\$ 145$ to \$245. Economic Report of the President Transmited to the Congress, H.R. 
elected a President who, as a candidate, was thought to favor a return to the gold standard. ${ }^{4}$ In March 1982 a Gold Commission, mandated by Congress and appointed by the Secretary of the Treasury, concluded that a restoration of the gold standard was not desirable, although it recommended a minor step in that direction. Nevertheless, the return of the gold standard, though actively opposed by the Treasury, has remained a first priority for a small but highly articulate group of economists and writers who have popularized the concept of supply side economics and who consider a return to the gold standard essential to the success of supply side policies. ${ }^{6}$

In fact, legislation during the 1970's had already undone most of the legislative steps taken under Roosevelt's leadership to eliminate gold from American monetary law: citizens may now buy and sell gold freely, ${ }^{7}$ and gold clauses are once again enforceable. ${ }^{8}$ The Gold Commission recommended the further step of a "Treasury issue of gold bullion coins of specified weights," albeit "without dollar denomination or legal tender status."9

Even if the movement toward a gold standard goes no further-and its future appears doubtful-the evolution in the role of gold in the half century since 1933 warrants study for its own inherent interest and because it sheds light on the meaning of any return to a gold standard. The emotion, ideology, and confusion surrounding public discussion of the gold standard can best be avoided by sober review of the evolving role of gold since the Roosevelt decisions. Emphasis here will be on the 1935 Gold

Doc. No. 97-3, 97th Cong., 1st Sess. 275 (1981) (Table B-37) [hereinafter cited as Economic REPORT (1981)].

- For President Reagan's pre-election position on gold, see N.Y. Times, Mar. 14, 1980, at D2, col. 1; id., Apr. 25, 1980, at A27, col. 1.

- 1 Report to the Congress of the Commission on the Role of Gold in the DomesTIC AND INTBRNational MONETARY SystzMS 1-21 (1982) [hereinafter cited as Gold CommisSION REPORT].

- I refer particularly to Arthur Laffer, Lewis Lehrman, and Jude Wanniski. Lehrman was a member of the Gold Commission. See his minority report (filed jointly with Congressman Ronald Paul) in 2 Gold Commission RBport, supra note 5, at 7.

7 Par Value Modification Act Amendments, Pub. L. No. 93-110, § 3(b), (c), 87 Stat. 352, 352 (1973) (codified in part at 31 U.S.C. $\$ 442$ (1976) and printed in part at 31 U.S.C. $\$ 443$ notes (1976)); Exec. Order No. 11,825, 3 C.F.R., 1971-75 Comp., at 929-30 (1976); see infra note 147 and accompanying text.

- Act of Oct. 28, 1977, Pub. L. No. 95-147, $\$ 4(c), 91$ Stat. 1227, 1229 (printed at 31 U.S.C. $\S 463$ note (1976)). A gold clause is a provision in a contract requiring "payment either in gold proper, or in a nominal amount of currency equal to the value of a specified weight of gold." M. Frirduan \& A. Schwaftz, A Monetary History of the United States 1867-1960, at 468 (1963).

- 1 Gold Commission Report, supra note 5, at 9. 
Clause Cases. ${ }^{10}$ This review suggests that the economic conditions that make a return to the gold standard most attractive also make it most unattainable.

To understand the Gold Clause Cases, it is useful to begin the analysis a half century earlier still, in 1879, when the United States first went on the gold standard. It is also useful to make a sharp, if somewhat unnatural, distinction between an international and a domestic gold standard.

The international gold standard, contrary to popular belief, had a relatively short life. It lasted only from 1879 , when the United States resumed payments of specie (that is, gold coin) in redemption of its currency, until 1914, when that standard collapsed as one of the first casualties of World War I. The international gold standard enjoyed a partial revival from 1925, when Britain returned to it, until 1931, when Britain again left it, or at the latest until 1933, when the United States abandoned it.11

The gold standard can also be thought of as a purely domestic set of legal rules. From that perspective one has an international gold standard only when nations accounting for the great bulk of international trade and investment have such a domestic standard. Indeed, the international gold standard was never much more than the international result and interaction of domestic gold standard rules. ${ }^{12}$

A domestic gold standard may thus be in force in a particular country when it would be inaccurate to speak of an international gold standard. It is common to date the gold standard in Britain back to the early nineteenth ${ }^{18}$ or even the eighteenth century. ${ }^{14}$ And one can say that during much of the first half of the nineteenth century the United States, although de jure on a bimetallic standard, had a de facto gold standard because the official ratio between gold and silver was such that by the inexorable workings

10 Perry v. United States, 294 U.S. 330 (1935); Nortz v. United States, 294 U.S. 317 (1935); Norman v. Baltimore \& O.R.R., 294 U.S. 240 (1935) (consolidated for review with United States v. Bankers Trust Co.).

11 See generally K. DaM, The Rules of the Game 14-70 (1982). In order to economize on space, I shall refer the reader to RULES of THE GAME for more detailed discussion of a number of points and particularly for more extensive documentation.

12 Id. at 23-24.

13 Id. at $24-25$.

14 R. Hawtrey, The Gold Standard in Theory and Practice 66-68 (5th ed. 1947). 
of Gresham's law only gold coin circulated.15

The United States clearly was not on a gold standard for a period beginning in 1861, when the North, under the financial pressures of the Civil War, suspended specie payments. ${ }^{16}$ Gold coin continued to circulate freely although in limited quantity compared to the volume of paper money, which included United States notes made legal tender in satisfaction of debts. ${ }^{17}$ In what was later called a dual monetary system, gold coin rose to a premium and fluctuated daily in value, as measured by paper money. ${ }^{18}$

The resumption of specie payments did not occur until 1879 , when the premium on gold disappeared, and thereafter gold coin exchanged at parity with paper money. Gold coin thenceforth was worth in paper money the face amount of the coin, ${ }^{19}$ and the face amount equalled the market value of the gold content of the coin. ${ }^{20}$ There was no reason for these values to depart from one another because one could redeem paper money and receive gold coin. Or one could turn in gold coin and receive paper. Similarly, gold bullion could be minted into gold coins and gold coins could be melted down to be sold as bullion. ${ }^{21}$ In the Gold Standard Act of 1900 Congress eliminated the last vestiges of any role for silver as a monetary standard by declaring that "the dollar consisting of twenty-five and eight-tenths grains of gold nine-tenths fine ... shall be the standard unit of value, and all forms of money issued or coined by the United States shall be maintained at a parity of value with this standard, and it shall be the duty of the Secretary of the Treasury to maintain such parity."22 This statutory parity

1s See K. DAM, supra note 11, at 19-20, 22. It is more accurate to say that Gresham's law holds that cheap money drives out dear than that bad money drives out good. The precondition for its operation is a legally fixed relation between the prices of two kinds of currency and divergence of market prices from that fixed ratio. A fuller discussion of Gresham's law may be found in id. at 20. Before the Civil War, gold was overvalued at the mint; it was worth more as coin than as bullion on the market and hence was freely coined. The reverse was generally true of silver. See also M. Friedman \& A. Schwartz, supra note 8 , at 27 n.16.

10 See Dam, The Legal Tender Cases, 1981 Sur. Ct. Rev. 367, 370-82.

17 See M. Friedman \& A. Schwartz, supra note 8, at 17 (Chart 1), 25-27.

12 Id. at 26, 65 (Chart 5).

10 See A. Nussbaum, A History or the Dollar 130-31 (1957).

20 This equality held when the coin was newly minted, but wear or clipping could reduce a gold coin's weight and hence the value of the gold that it contained.

21 For citations to the relevant statutes in force at the beginning of the Roosevelt Administration, see Brief for the United States at 13-19 nn.16-23, Nortz v. United States, 294 U.S. 317 (1935), reprinted in 29 LANDMARK BRIEFS AND ARgUMENTS OF THE SUPREME CoURT of the United States 551, 567-69 nn.16-23 (P. Kurland \& G. Casper eds. 1975) [hereinafter cited as Kurland \& Casper].

${ }^{22}$ Act of Mar. 14, 1900, ch. 41, § 1, 31 Stat. 45, 45 (current version at 31 U.S.C. $\S 314$ 
policy was to play a crucial role in the Gold Clause Cases.

Parity of gold coin, paper money, and bullion, simultaneously in force in all commercially important countries, was the hallmark of the international gold standard. One can see that fixed exchange rates would result from such national systems so long as gold could be imported and exported freely in each country. Moreover, using present-day terminology, gold was the principal international reserve asset, although after the Great War the increasing use of foreign exchange as reserves led the variant of the gold standard in operation from 1925 to 1933 to be called a "gold exchange" standard..$^{23}$ However, the essential element in the international gold standard-and this is a crucial point in contemporary discussions of a return to the gold standard-was that there was a close link between the domestic money supply in each country and its gold holdings. ${ }^{24}$ It was an "essential element of the classical gold standard ... that the money supply must be limited by the gold reserves and a change in the gold reserves should be followed by a change in monetary policy."2s In part this link was reflected in "gold cover requirements," such as the provision of United States law specifying the value of gold that had to "back" issuances of currency. ${ }^{26}$ More fundamental were the institutional arrangements in each country causing increased or decreased public gold holdings to lead respectively to a larger or smaller money supply. ${ }^{27}$

Whether the circulation of gold coin was essential to a gold standard, either domestic or international, may be debated. Certainly many countries, though not the United States, suppressed gold coin circulation after World War I in order to concentrate gold reserves in their central banks in defense of their currencies. ${ }^{28}$ But the free import and export of gold bullion in response to changing economic conditions left the gold standard essentially in-

(1976)) (emphasis added).

${ }^{23}$ See generally K. DAM, supra note 11, at 55-57, 64-69.

24 The process by which gold flows, under the international gold standard, financed payment imbalances and adjusted credit conditions and price levels is the subject of a vast amount of writing, which has continued to the present day. See, e.g., National Bureau or Econ. Research, Inc., Rep. No. 17, A Retrospective on the Classical Gold Standard, 1821-1931 (summer 1982) (report of a conference held by the National Bureau of Economic Research, Inc., Mar. 18-21, 1982).

${ }^{25}$ Bernstein, Is a Return to the Gold Standard Feasible?, in 2 Gold Commission RsPORT, supra note 5, at 310,314 .

${ }^{28}$ Federal Reserve Act, ch. 6, $\S 16,38$ Stat. 251, 266 (1913) (current version at 12 U.S.C. $\S \S 411-416,418-421,248,360$ (1976)); see infra note 133.

${ }^{27}$ See K. DAM, supra note 11, at 25-28, 42-43, for the operation of such institutional arrangements in Britain before and after the first world war. See also id. at 57-58.

${ }^{28} I d$. at $43,55-56$. 
tact, to the extent that monetary authorities did not try to attenuate the impact of international gold flows on their domestic money supply by offsetting transactions. Such offsetting transactions, apparently already significant before World War I, became common during the 1925-33 restoration of the international gold standard. ${ }^{29}$

\section{II}

By the time Roosevelt came to office the gold standard was near collapse. Britain left it in 1931 under the pressure of gold outflows and sterling weakness. Sterling depreciated sharply against the dollar. Many other countries were forced to follow suit, ${ }^{30}$ leaving the United States and the small European "gold bloc" as isolated adherents to the gold standard. ${ }^{31}$

When, in his first week in office, Roosevelt took the United States off the gold standard, he was not forced to do so by circumstances of the kind that had earlier impelled Britain to abandon it. Though the depreciation of a number of other currencies had hurt U.S. exports and increased imports to the detriment of U.S. manufacturers and though the United States lost one-fifth of its monetary gold stock between September 1931 and July 1932, it nevertheless held more gold at the beginning of March 1933 than it had in 1929 , the heyday of the post-War gold standard..$^{32}$ Rather, as we shall see later, Roosevelt chose to leave the gold standard in order to gain freedom to increase domestic prices, especially farm prices, without any constraints from the gold standard. Indeed, he wanted to use various gold transactions, domestic and foreign, to raise prices..$^{3 s}$

Roosevelt rapidly eliminated all of the elements of a gold stan-

29 Id. at 30-31, 58-59.

20 See Brief for the United States and the Reconstruction Finance Corporation at 38 \& n.16, United States v. Bankers Trust Co., 294 U.S. 240 (1935) (chronological list of countries abandoning the gold standard), reprinted in Kurland \& Casper, supra note 21, at 262 \& n.16.

32 Id. at 38-39, reprinted in Kurland \& Casper, supra note 21, at 262-63. The few remaining "gold bloc" countries of Europe-France, Belgium, the Netherlands, Poland, and Switzerland-temporarily sustained the gold standard but were forced to abandon it in 1935-36. Others, such as Germany and Italy, had not officially suspended gold payments but had imposed foreign exchange regulations that effectively negated its operation. Many nonEuropean countries, such as Canada, India, Japan, Chile, and Mexico, had abandoned the gold standard in 1931-32. See also L. Chandler, American Monetary Policy 1928-41, at 302-04 (1971); Foreign Banking and Business Conditions, Annual Report of the Bank for International Settlements, 21 FED. RESERVE BuLL. 360, 360-61 (1935); Review of the Month, 21 FED. REsBrve Bull. 257, 260-61 (1935).

32 See Review of the Month, 19 FEd. Reserve Bull. 209, 212 (1933).

2s See infra notes 41-43 and accompanying text. 
dard. On March 6, 1933, he used the dubious authority of the 1917 Trading with the Enemy Act ${ }^{34}$ to prohibit banks from paying out or exporting gold coin and bullion. ${ }^{35}$ International gold flows became impossible, and any immediate link between gold and the money supply was effectively terminated. Roosevelt knew what he was doing. At a press conference two days later he joked, "[a]s long as nobody asks me whether we are off the gold standard or gold basis, that is all right, because nobody knows what the gold basis or gold standard really is," ${ }^{36}$ but after some obfuscation about the elements of a gold standard, he conceded that "what you are coming to now really is a managed currency." ${ }^{\text {st }}$ On March 9 he sought confirming legislation, ${ }^{38}$ which was delivered that very day in the Emergency Banking Act, ${ }^{39}$ empowering the Secretary of the Treasury to require the surrender of all gold coin, gold bullion, and gold certificates against payment of paper money of the same face value. This power to "nationalize" gold was promptly implemented. ${ }^{40}$

These steps were taken at a time when "inflation" had wide support, support that was not restricted to populists, agrarians, radicals, and the silver lobby but that also embraced businessmen

s4 Ch. 106, § 5(b), 40 Stat. 411,415 (1917) (current version at 12 U.S.C. § 95a (1976); 50 U.S.C. app. $\S \S 1-44(1976))$. The Trading with the Enemy Act granted special powers in response to wartime conditions.

ss See Proclamation No. 2039 (Mar. 6, 1933), reprinted in 2 FDR PaPERs, supra note 1, at 24.

s6 2 FDR PAPERS, supra note 1, at 33-34.

s7 Id. at 36 .

ss Id. at 45-46 (Recommendation to the Congress for Legislation to Control Resumption of Banking (Mar. 9, 1933)).

38 Ch. 1, § 3, 48 Stat. 1, 2 (1933) (current version at 12 U.S.C. $\S 248$ (1976)).

40 See Exec. Order No. 6073 (Mar. 10, 1933) (prohibiting gold payments and exports) (amended by Proclamation No. 2725, 12 Fed. Reg. 2343 (1947); revoked in part by Exec. Order No. 11,825 (Dec. 31, 1974), 40 Fed. Reg. 1003 (1974), which is printed at 12 U.S.C. 95a note (1976)), reprinted in 2 FDR PAPERS, supra note 1, at 54; Exec. Order No. 6102 (Apr. 5, 1933) (requiring delivery of gold coin, gold bullion, and gold certificates to the government), reprinted in 2 FDR PAPERs, supra note 1, at 111; Exec. Order No. 6111 (Apr. 29, 1933) (defining the Secretary of the Treasury's authority to embargo gold exports), reprinted in 2 FDR PAPERS, supra note 1, at 141. See also Regulations Relating to Licensing the Purchase and Export of Gold, 19 FED. Reserve BulL. 267 (1933). Executive Orders Nos. 6102 and 6111 were replaced and amended by Exec. Order No. 6260 (Aug. 28, 1933) (amended by Exec. Order No. 10,896 (Nov. 29, 1960), 25 Fed. Reg. 12,281 (1960), Exec. Order No. 10,905 (Jan. 20, 1962), 26 Fed. Reg. 321 (1961), Exec. Order No. 11,037 (July 20, 1962), 27 Fed. Reg. 6967 (1962), and revoked by Exec. Order No. 11,825 (Dec. 31, 1974), 40 Fed. Reg. 1003 (1974)), reprinted in 2 FDR PAPERS, supra note 1, at 345, and by Exec. Order No. 6556 (Jan. 12, 1934) (printed at 12 U.S.C. \& 95a note (1976)). Exec. Order No. 6261 (Aug. 29, 1933) then governed sale of newly mined domestic gold through the Treasury, 2 FDR PAPERS, supra note 1, at 352. 
and banking experts, such as Marriner Eccles and Representative Steagall, and the disparate members of the Committee for the Nation. ${ }^{11}$ There was no unanimity, however, as to the methods for achieving inflation and the rationales offered as to why they would work. Roosevelt, with his famous "flexibility," appears to have selected method and rationale according to the needs of the moment. His goal was to achieve higher prices. But he was not a monetarist and his strategy turned less on inflating the money supply ${ }^{42}$ (although breaking the link with gold facilitated this effect) than on direct means to increase prices. The National Recovery Administration's much publicized system of industrywide production cartels is a characteristic example. To Roosevelt, another means was devaluation of the dollar. The effect would be, in his view, to raise directly and proportionately the prices of farm products and raw materials traded internationally and perhaps to raise other prices as well.43

Congressional authorization to devalue the dollar was obtained less than ten weeks after Roosevelt's inauguration. In accordance with the accepted view of the matter, the legislation was phrased in terms of authority to reduce the weight of the gold dollar.4 Roosevelt did not exercise that authority immediately and indeed

12 See M. Eccles, Beckoning Frontiers 122-24, 129-32 (1951); see also A. Schlesinger, The Age of Roosevelt: The Coming of the New Deal 41-42, 195-99 (1959). Eccles, a Utah banker and industrialist, was appointed Governor of the Federal Reserve Board by Roosevelt. See M. Eccles, supra, at 175-76. Steagall was chairman of the House Banking and Currency Committee.

42 For example, although the Thomas Amendment to the Agricultural Adjustment Act, ch. $25, \S 43(\mathrm{a}),(\mathrm{b})(1), 48$ Stat. 31, 51-52 (1933) (current version of $\S 43(\mathrm{a})$ at 31 U.S.C. $\S 821$ (1976); (b)(1) repealed 1945 \& 1965), provided for expansion of Federal Reserve credit by $\$ 3$ billion and the issuance of a like amount of fiat currency, Hurst argues that these easy money measures were "forced on a reluctant president by congressmen moved partly by business expansionists [and] by traditional farmer favor for easy money." J. HURST, A LEgal History of Mongy in the United States, 1774-1970, at 232 (1973).

is See 3 FDR Papers, supra note 1, at 70-73. See also M. Friedman \& A. Schwartz, supra note 8 , at 464-66 (on the measures used to raise commodity prices). Roosevelt apparently did not favor inflation for its own sake. Rather he sought to offset the decline in producer prices that had already taken place. See 2 FDR PAPERS, supra note 1, at 74-79. In July 1933 he told the London Economic Conference that his long-run goal was "the kind of dollar which a generation hence will have the same purchasing and debt-paying power as the dollar value we hope to attain in the near future." Id. at 265.

"Agricultural Adjustment Act, ch. 25, § 43(b)(2), 48 Stat. 31, 52-53 (1933) (authorization expired in 1943 following an amendment that extended this presidential power to 1939 and added an automatic expiration clause, Act of Jan. 23, 1937, ch. 5, § 2, 50 Stat. 4, 4 (1937), and following later amendments that extended the power to 1941 and 1943 respectively, Act of July 6, 1939, ch. 260, § 3, 53 Stat. 998, 998; Act of June 30,1941 , ch. 265, § 2, 55 Stat. 396,396 . On the provision regarding weight of the gold dollar, see infra text accompanying note 57 . 
waited until January 31,1934 , to do so. ${ }^{45}$ Rather, at the behest of the Administration, Congress first took the precaution by a Joint Resolution of June 5, 1933, of invalidating gold clauses in public and private contracts. ${ }^{46}$ This Joint Resolution provided that "every provision . . . with respect to any obligation which purports to give the obligee a right to require payment in gold or a particular kind of coin or currency . . . is . . . against public policy" and that all past or future obligations, "whether or not any such provision is contained therein ... shall be discharged upon payment, dollar for dollar, in any coin or currency which at the time of payment is legal tender." 17 One purpose, and in retrospect the most important purpose, was to give "private debtors with gold clause obligations ... protection and a prompt and clear definition of their legal position" 48 - in short, to assure that creditors would not be able to enforce gold clauses when the dollar was devalued.

Before discussing how the Supreme Court dealt with the Joint Resolution when it first came before it in 1935, it is worth noting how Roosevelt dealt with gold issues in the interim. The departure from the gold standard had permitted a sharp rise in the gold price even before the Joint Resolution. In addition, the dollar depreciated by nearly fifteen percent against the French franc (which was still on gold) between mid-April and early May 1933.49 But Roosevelt, faced by a renewed decline in prices and agricultural unrest, was not content with market forces and sought to induce greater dollar depreciation over the course of the autumn of 1933 by a concerted gold buying program. ${ }^{\text {s0 }}$ The Reconstruction Finance Corporation ("RFC") began to buy not merely newly mined U.S. gold but also existing gold in the world market. ${ }^{51}$ Though Attorney General Homer Cummings and RFC General Counsel (later Su-

43 See infra notes 57-59 and accompanying text.

46 Ch. $48, \S 1,48$ Stat. 112, 113 (1933) (codified at 31 U.S.C. $\$ 463$ (1976)). On the role of the Administration see Review of the Month, 19 FED. Reserve Bull. 331, 333 (1933). For differing explanations of the Administration's anxiety for quick passage of the Joint Resolution, see N.Y. Times, June 5, 1933, § 1, at 14, col. 1; id., June 6, 1933, § 1, at 35, col. 8. See also Second "Fireside Chat" (May 7, 1933), reprinted in 2 FDR PAPRRS, supra note 1, at $160,165-66$.

47 Ch. $48, \S 1,48$ Stat. 112, 113 (1933) (codified at 31 U.S.C. $\S 463$ (1976)).

48 S. Rep. No. 99, 73d Cong., 1st Sess. 1 (1933), reprinted in 19 Fed. Reserve Bull. 334 (1933).

19 M. Friedman \& A. Schwartz, supra note 8, at 465; Review of the Month, 19 Fed. Reserve Bull. 331, 333, 342 (1933).

so See D. Acheson, supra note 1, at 174-78; J. Warburg, The Money MuddLe, 135-46 (1934); see also A. SchLESINGER, supra note 41 , at 234-41.

s1 Fourth "Fireside Chat" (Oct. 22, 1933), reprinted in 2 FDR PAPERS, supra note 1, at 420, 426-27. 
preme Court Justice) Stanley Reed formally opined that the RFC gold buying program was authorized by statute, ${ }^{52}$ Undersecretary of the Treasury Dean Acheson resigned because he thought that he was implicated in an unconstitutional program..$^{53}$

The gold buying program succeeded in raising the price of gold from an initial price of $\$ 31.36$ an ounce to $\$ 34.45$ by January 1934. ${ }^{54}$ The dollar depreciated more or less to the same extent in foreign exchange markets, ${ }^{\mathrm{bS}}$ although Keynes characterized the "recent gyrations of the dollar" as "more like a gold standard on the booze than the ideal managed currency of my dreams." ${ }^{\prime 36}$ On January 15, 1934, the President acted to stabilize and consolidate the results of his policy. He requested authority to devalue the dollar in terms of gold to between fifty and sixty percent of its original value (though he had already secured authority to devalue to fifty percent ${ }^{\mathrm{Bz}}$ ) and authority for the Treasury to buy and sell gold and foreign exchange to stabilize the dollar in foreign exchange

32 See 37 Op. Att'y Gen. 315 (1936) (Cummings); D. Acheson, supra note 1, at 261-66 (Reed opinion).

ss See D. Achrson, supra note 1, at 177-78, 180-82, 186-92. Reed's and Acheson's opinions on the program's constitutionality are printed side-by-side by Acheson. See id. at 26166. Acheson privately consulted Justice Brandeis, who refused to give a private ruling, stating, "Dean, if I wanted a legal opinion, I would prefer to get it from you than from [Attorney General] Homer Cummings." Id. at 181. The ground of Acheson's resignation was his objection to the method of buying gold through the RFC. He accepted, however, the necessity for the Joint Resolution. Id. at 167, 186-92.

-4 See Other Banking and Financial Statistics, 20 Fed. Reserve Bull. 133 (1934); Review of the Month, 19 FrD. RaskRve BuLl. 669, 676 (1933).

ss 19 Fed. Reserve Buld. 679, 740 (1933); 20 FEd. RESERve Bull. 91 (1934). Friedman and Schwartz have argued that the same exchange rate effect "would have followed from the same dollar volume of government purchase of wheat or perfume or foreign-owned art masterpieces." M. Frisdman \& A. SchwarTz, supra note 8, at 466. This clearly was not the view of influential U.S. government officials at the time who thought gold played a unique role in determining exchange rates. See D. AcHeson, supra note 1 , at 174-75, for the views of the group centered around Henry Morgenthau and George F. Warren: "The only way to [raise commodity prices] is by controlling the gold value of the dollar and forcing it downward." Id. at 175. On Roosevelt's own view of the gold buying policy as a means of depressing the gold value of the dollar, see his January 15, 1934, press conference, 3 FDR PaPERs, supra note 1 , at $46,48-49,53$.

se Letter from John Maynard Keynes to President Roosevelt (Dec. 1933), reprinted in Roosevelt and Frankrurter: Their Correspondence, 1928-45, at 181 (M. Freedman annot. ed. 1967) [hereinafter cited as RooszVELT AND FrANKPURTER]. Keynes was not alone in his strictures on the "instability" resulting from the gold-buying policy. See the "influential" letter of criticism and advice from a group of Oxford economists to the President (Nov. 1933), reprinted in RoosevELT AND FRANKPURTBR, supra, at 168-73, and its attentive reception in Washington, Letter from President Roosevelt to Felix Frankfurter (Dec. 22, 1933), reprinted in Roosevelt AND Frankpurter, supra, at 183-84. See also A. Schlesinger, supra note 41, at 245-46; J. WARBURG, supra note 50, at 154-59.

s7 See M. Frisdman \& A. Schwartz, supra note 8, at 465; see also supra notes 42,44 45 and accompanying text (discussion of the Thomas Amendment). 
markets. ${ }^{58}$ The authority was promptly granted in the Gold Reserve Act and on January 31, 1934, the President proclaimed a new gold content of 15-5/21 grains $9 / 10$ fine gold, a reduction to $59.06 \%$ of the former weight, equal to an official gold price of thirty-five dollars an ounce..$^{59}$

The Gold Reserve Act of 1934 took one further step to eradicate remaining gold standard symbols. In Roosevelt's own words, the Act "abolished gold coin as a component of our monetary system." All gold coin was to be withdrawn from circulation and formed into gold bars. ${ }^{61}$ Even the Treasury was thenceforth to hold gold only in the form of bullion. ${ }^{62}$ Gold was thereafter to be a commodity, not money. It could be sold for industrial and dental uses. Coin collectors could still hold gold coins but only those of numismatic value. ${ }^{63}$ Although U.S. citizens could not hold gold in the United States, they could deal freely in gold "situated outside the United States," ${ }^{\circ 4}$ a privilege not withdrawn until the Kennedy Administration. ${ }^{65}$

\section{III}

The four major gold clause cases were decided by the Supreme Court in $1935 .^{.6}$ The cases of Norman v. Baltimore \& Ohio Railroad and United States $v$. Bankers Trust Co. were decided together $^{67}$ and involved private obligations. In both, the Joint Resolution invalidating gold clauses was held constitutional, and corporate bonds containing gold clauses were therefore held dis-

${ }^{88}$ Request for Legislation to Organize a Sound and Adequate Currency System, January 15, 1934, reprinted in 3 FDR PAPERs, supra note 1 , at 40, 42-43.

Bo Gold Reserve Act of 1934, ch. 6, $\$ \S 10,12,48$ Stat. 337, 341-43 (current version at 31 U.S.C. $\S \S 314,821,822 \mathrm{a}$ (1976)); Proclamation No. 2072 (Jan. 31, 1934), and accompanying statement, reprinted in 3 FDR PAPERS, supra note 1, at 64-70.

0 Presidential Statement accompanying Proclamation No. 2072 (Jan. 31, 1934), reprinted in 3 FDR PAPERS, supra note 1 , at 75.

11 Gold Reserve Act of 1934 , ch. $6, \S 5,48$ Stat. 337,340 (current version at 31 U.S.C. $\S$ 315b (1976)).

${ }^{62}$ Id. $\$ 6$ (current version at 31 U.S.C. $\$ 408 a(1976)$ ).

as Provisional Regulations Issued Under the Gold Reserve Act of 1934, § 20, 20 FED. REServe BuLl. 82, 85 (1934).

-4 Treasury statement of January 30, 1934, 20 FED. RESERve Bull. 81 (1934).

65 See infra notes $136-37$ and accompanying text.

6 See supra note 10. A fifth gold clause case was decided in 1937: Holyoke Water Power Co. v. American Writing Paper Co., 300 U.S. 324 (1937). See also Guaranty Trust Co. v. Henwood, 307 U.S. 247 (1939) (dealing with optional foreign payment of gold clause bonds); Smyth v. United States, 302 U.S. 329 (1937) (dealing with the call of United States Bonds containing gold clauses).

${ }^{67} 294$ U.S. 240 (1935). 
chargeable at the nominal face amount. ${ }^{68}$

The reasoning was straightforward. Congress had broad power over the value of money. The source of this monetary power was derived not merely from the coinage power expressly granted in the Constitution ${ }^{89}$ but from

the aggregate of the powers granted to the Congress, embracing the powers to lay and collect taxes, to borrow money, to regulate commerce with foreign nations and among the several States, to coin money, regulate the value thereof, and of foreign coin, and fix the standards of weights and measures, and the added express power "to make all laws which shall be necessary and proper for carrying into execution" the other enumerated powers. ${ }^{70}$

In execution of those powers Congress had the power of "frustrating the expected performance of contracts," on private contractual relations did not constitute a taking under the fifth amendment. ${ }^{72}$ Since, under the circumstances prevailing in 1933, gold clauses constituted an "actual interference" with its broad monetary powers, Congress had the power to invalidate such clauses. ${ }^{73}$ As discussed below, the factual analysis leading to the conclusion that gold clauses interfered with the exercise of the monetary power is not wholly satisfactory. ${ }^{74}$ The legal reasoning, on the other hand, is unexceptionable, particularly to a modernday reader accustomed to vast congressional power over the economy.

The other two cases, Nortz $v$. United States ${ }^{78}$ and Perry $v$. United States, ${ }^{76}$ involved obligations of the federal government. In Nortz, a holder of gold certificates acting under compulsion of the nationalization orders and regulations had surrendered the certificates to the Treasury on January 17, 1934. At that time gold was being purchased by the Treasury at $\$ 34.45$ (and therefore traded on world markets at approximately that price) and two weeks later

es Id. at $302,316$.

so U.S. ConsT. art. I, § 8, cl. 5.

70 294 U.S. at 303 (quoting U.S. Const. art. I, \& 8, cl. 18). For a discussion of the limits of the coinage power and its relation to other bases of power over the value of money, see Dam, supra note 16 , at 391.

72 294 U.S. at 304; see also id. at 306-11.

32 Id. at 305.

73 Id. at $311,316$.

7" Infra part IV.

73294 U.S. 317 (1935).

76294 U.S. 330 (1935). 
the President, acting under authority he had sought from Congress on January $15,{ }^{77}$ had devalued the dollar, changing the official gold price from $\$ 20.67$ to $\$ 35.00$ per ounce. Nonetheless, the plaintiff, having sued for recovery at $\$ 33.43$ per ounce (the London price on January 17), was held to be entitled to be recompensed for his gold certificate only at the rate of $\$ 20.67$ per ounce. ${ }^{28}$

Hence, unlike the private obligation cases where the Court had held that no fifth amendment taking had occurred, the taking was conceded but "just compensation" was held to require payment only at the $\$ 20.67$ price. The theory was that even if gold coin had been paid out by the Treasury, the holder would have had no alternative but to return the coin to the Treasury and to be compensated at the official gold price. Since gold coin could not be sold at the $\$ 34.45$ bullion price available to gold producers and since it was then unlawful to export gold coin in order to receive the world price, the holder was entitled to no more than the nominal value of the certificate, which was calculated at the $\$ 20.67$ price. The Court emphasized that a gold certificate was currency, not a warehouse receipt for gold, but the decision did not turn on that point. In effect, price controls had held the price of gold certificates to $\$ 20.67$, and so the holder was entitled to no more. ${ }^{79}$

Perry, a case involving a 1917 U.S. government bond that was called for redemption in April 1934, ${ }^{80}$ extended the Nortz reasoning. Because the $\$ 10,000$ bond made principal and interest " 'payable in United States gold coin of the present standard of value" "\$81 and because under prior Supreme Court rulings U.S. government obligations could not be invalidated by subsequent legislation, ${ }^{\mathbf{2 2}}$

77 See supra note 59 and accompanying text.

78294 U.S. at 330 . Nortz claimed that on January 17, 1934, "an ounce of gold was of the value at least of $\$ 33.43$." Id. at 329. The official U.S. price on that day was $\$ 34.45$. $20 \mathrm{FzD}$. Reserve Bull. 133 (1934). For London prices, see Plaintiff's Reply Brief at 5 n.2, Nortz v. United States, 294 U.S. 317 (1935), reprinted in Kurland \& Casper, supra note 21, at 597 n.2. Under legislation originally enacted during the Civil War, the Treasury could issue gold certificates against deposits or holdings of gold coin and bullion. In 1919 gold certificates were made legal tender. For the relevant legislation, see the summary in the Nortz opinion, 294 U.S. at 325-26.

70294 U.S. at $328-30$.

so 294 U.S. at 347.

81 Id. (quoting terms of bond).

${ }^{82}$ See The Sinking-Fund Cases, 99 U.S. 700 (1879). See also Lynch v. United States, 292 U.S. 571, 580 (1934), a case decided the previous Term, in which the Court in an opinion by Justice Brandeis ruled that Congress did not have the power to repudiate contractual insurance obligations of the United States. See generally U.S. CoNST. amend. XIV, \& 4 ("The validity of the public debt of the United States, authorized by law, . . . shall not be questioned."). 
Chief Justice Hughes, speaking for a four-member plurality, ruled the Joint Resolution unconstitutional insofar as it applied to gold clauses in such obligations. ${ }^{83}$ But the Court nonetheless relegated the holder of the government bond to receiving merely the face amount of $\$ 10,000$ in legal tender currency. The Court reasoned that unlike the post-Civil War period, when coin and paper money floated in the marketplace at prices determined by supply and demand, the period of the Gold Clause Cases had a "single monetary system with an established parity of all currency and coins."84 Even under the pre-1933 legislation, a gold coin could have been legal tender only for its face amount, not for the value of its gold content. Thus even if the bond had been paid in gold coin and even assuming that gold coin did not have to be surrendered to the government at the $\$ 20.67$ price under the 1933 regulations, the bondholder could not have exchanged his gold coin at the thirtyfive dollar price because no recipient. would have been required to treat it as legal tender for more than its face amount. Moreover, he could not have exported the gold coin or sold it for its gold content. As a result, the holder had no legally cognizable loss of purchasing power. ${ }^{85}$ Since there was no "actual loss," recovery of money at the gold value- $\$ 1.69$ per $\$ 1.00$ face amount of the bonds-would "constitute not a recoupment of loss in any proper sense but an unjustified enrichment."

The reasoning on the lack of damages in Perry was convoluted and suspect, as a fledgling Harvard law professor, Henry Hart, made clear in justifying his conclusion that "[f]ew more baffling pronouncements, it is fair to say, have ever issued from the United

ss See 294 U.S. at 346-58. Because Justice Stone, the fifth member of the five-man majority, concurred specially, there was no opinion of the Court in Perry. Stone's concurrence, $i d$. at 358, was limited to the question of the claimant's entitlement "to receive from the United States an amount in legal tender currency in excess of the face amount of the bond," id. at 347. He aligned himself with Hughes in holding that there was "no damage because Congress, by the exercise of its power to regulate the currency, has made it impossible for the plaintiff to enjoy the benefits of gold payments promised by the Government." Id. at 360 (Stone, J., concurring). However, he refrained from ruling on any wider constitutional question, and thought it "undesirable, for the Court to undertake to say that the obligation of the gold clause in Government bonds is greater than in the bonds of private individuals." Id. at 359 (Stone, J., concurring). See A. Mason, Hardan Fiske Stons 391-92 (1956). In all four Gold Clause Cases, four Justices-McReynolds, Van Devanter, Sutherland, and Butler-dissented.

44 294 U.S. at 357. This was largely as a result of the parity clause of the Gold Standard Act of 1900 . See supra note 22 and accompanying text.

as 294 U.S. at $356-58$.

se Id. at 358. 
States Supreme Court."8z Hart was anxious to show that the Joint Resolution was constitutional even as applied to government gold clause obligations. The reasoning of the Perry plurality on the constitutional issue was, however, less important to the future of gold than was the result, which rendered gold clauses just as ineffective in government obligations as in private obligations. ${ }^{88}$ More interesting therefore are the economic and social reasons that led a majority of the Court to invalidate, de jure for private obligations and de facto for public obligations, solemn promises that had been bargained for with the very eventuality in mind that led to their invalidation-the depreciation of the currency in terms of gold.

\section{IV}

In considering the factual basis for the Court's finding of an "actual interference" with the monetary power of Congress, it is first useful to clear away an issue of interpretation of the gold clauses themselves. Were they "gold coin" or only "gold value" clauses? If the former, then the creditor could claim gold coin. The consequence of their enforcement might then be, as the Court reasoned in Norman, "to increase the demand for gold, to encourage hoarding, and to stimulate attempts at exportation of gold coin," which would indeed conflict with the congressional policy of calling in all privately held gold. ${ }^{89}$ If, despite the explicit wording calling for payment " 'in gold coin" " or " 'in United States gold coin," ", the clauses could be interpreted as merely requiring payment of the present day currency equivalent of the promised gold coin, then no impact on gold holdings, public or private, could be anticipated. During the greenback period, the Supreme Court had been wont to construe gold clauses as "gold coin" clauses in order to protect creditors from the legal tender legislation. ${ }^{91}$ As both the Permanent Court of International Justice ${ }^{\mathbf{9}}$ and the British House

87 Hart, The Gold Clause in United States Bonds, 48 HaRv. L. REv. 1057, 1057 (1935).

ss The constitutional justification for the 1933 Joint Resolution and the legal reasoning in the Gold Clause Cases have been subjected to voluminous analysis. Among the best articles are Dawson, The Gold Clause Decisions, 33 Mrch. L. Rev. 647 (1935), Dickinson, The Gold Decisions, 83 U. PA. L. Rev. 715 (1935), and Hart, supra note 87.

so Norman, 294 U.S. at 313.

20 Id. at 293 (quoting terms of bond); Perry, 294 U.S. at 347 (quoting terms of bond).

91 See, e.g., Trebilcock v. Wilson, 79 U.S. (12 Wall.) 687 (1872); Dewing v. Sears, 78 U.S. (11 Wall.) 379 (1871); Butler v. Horwitz, 74 U.S. (7 Wall.) 258 (1869); Bronson v. Rodes, 74 U.S. (7 Wall.) 229 (1869). See also Thompson v. Butler, 95 U.S. 694 (1878) (Court held the amount in controversy was insufficient to give it jurisdiction). But see Gregory v. Morris, 96 U.S. 619 (1878) (treating a gold clause as a gold bullion clause).

${ }^{92}$ Concerning the Payment of Various Serbian Loans Issued in France (Fr. v. Serbia), 
of Lords ${ }^{93}$ had more recently treated gold clauses as "gold value" clauses, however, the 1935 Supreme Court was willing to treat the clauses before them as "gold value" clauses. ${ }^{94}$ Once that concession was made, the Court's concern to protect the congressional decision to "choose . . . a uniform monetary system, and to reject a dual system"9s became irrelevant because gold value clauses could be enforced without according any monetary role to gold. It would suffice to determine the present market value of gold equal to coins of the weight and fineness referred to in the contractual clause-which in Norman was " "gold coin of the United States of America of or equal to the standard weight and fineness existing on February 1, 1930." "98

The question consequently became how requiring a private debtor to pay $\$ 1.69$ instead of $\$ 1.00$ for each face dollar of principal and interest would interfere with the monetary power of Congress. In attempting to give a satisfactory answer to that question, the Court emphasized the large volume of gold clause obligations. The result of enforcing the clauses, even on a gold value basis, would be "dislocation of the domestic economy." not bother to explain the causation or nature of the dislocation. Rather, it contented itself with the rhetorical flourish that "[i]t requires no acute analysis or profound economic inquiry to disclose" the dislocation that would result if "debtors under gold clauses should be required to pay one dollar and sixty-nine cents in currency while respectively receiving their taxes, rates, charges and prices on the basis of one dollar of that currency."98 Yet "analysis," whether "acute" or otherwise, of why it would harm the economy, as opposed to individual debtors, to give effect to bargained-for promises was totally lacking in the Gold Clause Cases. Some corporations might indeed become insolvent if the debt were interpreted to be $\$ 1.69$ rather than $\$ 1.00$, but that need not necessarily result in either lower output or higher unemployment in the economy.

1929 P.C.I.J., ser. A, No. 20, at 48 (Judgment of July 12); Concerning the Payment in Gold of the Brazilian Federal Loans Issued in France (Fr. v. Braz.), 1929 P.C.I.J., ser. A, No. 21, at 110 (Judgment of July 12).

's Feist v. Société Intercommunale Belge d'Electricité, 1934 A.C. 161, 175 (H.L. 1933).

* See Norman v. Baltimore \& O.R.R., 294 U.S. at 302, 314. For a more elaborate tripartite distinction among types of gold clauses, see Hart, supra note 87, at 1060-61 n.13.

294 U.S. at 316.

or Id. at 293 (quoting terms of bond).

or Id. at 315 .

"Id. at $315-16$. 
The government's brief in Bankers Trust made some effort to calculate the impact of holding gold clauses valid. It analyzed debt service (interest plus amortization of principal) and concluded that enforcement of gold clauses on both public and private debts would raise annual debt service some $\$ 3.0$ billion to more than $\$ 10.9$ billion. ${ }^{99}$ This was not an insubstantial amount in an economy with a gross national product of $\$ 55.8$ billion. ${ }^{100}$ But it was in no sense a monetary drain since every dollar paid was received by someone else. And then, as at other times, the principal of longterm debt was often refinanced.

The burden of debt service was largely attributable not to the gold clauses but to a sharp decline in the gross national product from $\$ 103.4$ billion in 1929 to the 1933 figure of $\$ 55.8$ billion. A large portion of this decline represented a fall in prices. Wholesale prices had fallen by one-third between 1929 and $1932 .{ }^{101}$ Fixed price obligations became much more burdensome, just as they became less burdensome during the inflation of the 1970's, when the consumer price index approximately doubled. ${ }^{102}$ Nevertheless, none of the parties made any attempt to justify invalidation of gold clauses (when construed as gold value clauses) on strictly economic grounds by evaluating the effects of enforcement using such economic criteria as production of goods and services or unemployment.

In the face of this paucity of economic evidence or even layman's economic reasoning, it is worth examining the possibility that something quite different motivated President Roosevelt, the Congress, and the Court. The most reasonable hypothesis is that the purpose of prohibiting the enforcement of clauses even on a gold value basis was to redistribute income from creditors to debt-

s9 See Brief for the United States and the Reconstruction Finance Corporation at 35 n.14, United States v. Bankers Trust Co., 294 U.S. 240 (1935), reprinted in Kurland \& Casper, supra note 21 , at 259 n.14. The government's brief later used somewhat different and partially inconsistent numbers. See id. at 48-53, reprinted in Kurland \& Casper, supra note 21, at 272-77. See also estimates based on a detailed list of U.S. obligations outstanding on May 31, 1933, in Brief for the United States at 13 n.12, Perry v. United States, 294 U.S. 330 (1935), reprinted in Kurland \& Casper, supra note 21, at 685 n.12.

100 See Economic Report (1981), supra note 3, at 233 (Table B-1).

101 See id. (table of gross national product from 1929 to 1980). See also Brief for the United States and the Reconstruction Finance Corporation at 33, United States v. Bankers Trust, 294 U.S. 240 (1935) (table and chart for U.S. wholesale commodity prices), reprinted in Kurland \& Casper, supra note 21, at 257.

${ }^{102}$ Changes in methods of tabulation make it difficult to compare the wholesale price indexes for 1929-32 with those published for the 1970's. The consumer price index rose from 116.3 in 1970 to 229.9 in December 1979. See Economic RePorT (1981), supra note 3, at 289 (Table B-50). 
ors. Certainly the President in a moment of economic candor took the position that the purpose of the Joint Resolution was "to prevent unfair profits from accruing to a very small group of creditors and the placing of unfair burdens ... on the corresponding debtors" through enforcement of gold clause promises. ${ }^{103}$ Such profits he considered "unearned." He had wanted "[t]o restrict the 'unjustified enrichment'-the unearned profit from gold and foreign exchange-which at other times here and at all times in most other Nations was permitted to fall to a privileged few as a result of governmental monetary action." ${ }^{104}$ The Court did not quite adopt the redistributive notion that it would be unfair to allow creditors to benefit from the enforcement of debtors' promises, but it did endorse the idea that enforcement would be unfair to the debtor in the context of a devaluation of the dollar in terms of gold. It is unfairness to the debtor, rather than any macroeconomic concept, that appears to lie behind the otherwise puerile observation previously noted that gold clause debtors would have to pay "one dollar and sixty-nine cents in currency while respectively receiving their taxes, rates, charges and prices on the basis of one dollar of that currency."10s

The willingness of the Court to endorse the redistributive desire to help debtors at the expense of creditors may seem rather odd when one considers that the actual obligors in the Gold Clause Cases were large railroads, banks, and the United States itself and that many of the bondholders were doubtless individuals, perhaps even "widows and orphans." But the government had gone out of its way to emphasize that gold clauses were common in farm and home mortgages. ${ }^{108}$ The Court had already revealed a willingness to uphold legislative interference with such mortgage obligations in the case of Home Building \& Loan Association v. Blaisdell. ${ }^{107}$

102 Roosevelt's explanatory note accompanying Proclamation No. 2072 (Jan. 31, 1934), reprinted in 3 FDR PAPERS, supra note 1, at 73.

${ }^{204}$ Id., reprinted in 3 FDR PAPRRS, supra note 1, at 70.

${ }^{108}$ Norman v. Baltimore \& O.R.R., 294 U.S. at 315-16. See supra text accompanying note 98.

100 See Brief for the United States and the Reconstruction Finance Corporation at 49, United States v. Bankers Trust Co., 294 U.S. 240 (1935), reprinted in Kurland \& Casper, supra note 21, at 273, which analogizes enforcement of gold clauses to "a tax per year of more than $\$ 20$ on every man, woman, and child in this country." See also id. at 50-51, reprinted in Kurland \& Casper, supra note 21, at 274-75; Stenographic Report of the Oral Argument of Honorable Homer Cummings, Attorney General of the United States, on behalf of the Government, at 33, Norman v. Baltimore \& O.R.R., 294 U.S. 240 (1935), reprinted in Kurland \& Casper, supra note 21, at 817.

107290 U.S. 398 (1934). 
The Gold Clause Cases cannot, however, be written off as an exercise in populism. It seems apparent from the tone of the opinions that the majority felt that enforcement of the gold clauses would not merely be unfair to debtors but would provide a windfall to creditors. Certainly the government so argued. ${ }^{108} \mathrm{How}$, one may ask, can it be a windfall to enforce a bargained-for promise in the very situation envisaged by the explicit words of the promise-a change in the value of the currency in terms of gold? ${ }^{100}$ There are two possible answers to that question, one essentially illegitimate and the other somewhat more weighty.

The illegitimate answer would be to deny that anyone actually bargained for the gold clauses. Some of the arguments before the Court implied that the gold clauses were mere boilerplate that had been included in loan agreements and mortgages by lawyers from time out of mind without attention from the borrower and lender. ${ }^{110}$ This boilerplate argument seems wrongheaded on two grounds. First, even if it were true that most or even all parties did not focus on the gold clause in their negotiations, it is hard to see why that should make any difference. Courts do not normally refuse to enforce form contracts merely because they are form contracts. Second, the gold clauses were originally inserted in contracts in the United States (unlike Great Britain, where gold clauses were relatively rare ${ }^{111}$ ) for concrete reasons. These clauses increased in importance with the Civil War greenback experience when Congress, by giving paper money legal tender quality, benefited debtors at the expense of creditors with respect to pre-ex-

108 "When claimant demands $\$ 16,931.25$ for his $\$ 10,000$ Liberty bond, he is not asking the Goverment to pay him what the Government actually received for the bond. He is not asking for payment of an equivalent amount; he is asking for a windfall." Brief for the United States at 60-61, Perry v. United States, 294 U.S. 330 (1935), reprinted in Kurland \& Casper, supra note 21, at 732-33.

${ }_{100}$ "Promises in contracts are not subject to defeat simply because they turn out to be to the advantage of the promisee. A contract is a bargain for enrichment, or for some other anticipated advantage, a bargain presumably made for satisfactory consideration." Hart, supra note 87 , at 1080 .

${ }^{110}$ See, e.g., Brief for the United States and the Reconstruction Finance Corporation at 114-18, United States v. Bankers Trust Co., 294 U.S. 240 (1935), reprinted in Kurland \& Casper, supra note 21, at 342 .

${ }^{111}$ Brief for the United States and the Reconstruction Finance Corporation at 68 n.29, United States v. Bankers Trust Co., 294 U.S. 240 (1935), reprinted in Kurland \& Casper, supra note 21, at $292 \mathrm{n}$.29. For surveys of international practice relating to gold clauses, see G. Delaume, Legal Aspects or International Lending and Economic Development FiNANCING 258-61, 267 n.22, 276-85 (1967); Nussbaum, Comparative and International Aspects of American Gold Clause Abrogation, 44 YALE L.J. 53, 60-65 (1934). 
isting contracts. ${ }^{112}$ Those creditors who had gold coin clauses were protected against inflation during the greenback period, and it would have been difficult for other creditors not to have learned their lesson, especially as the government itself issued gold clause obligations throughout the greenback period. ${ }^{113}$ The use of gold clauses received another boost from the free silver agitation of the late nineteenth century. ${ }^{114}$ In short, if gold clauses had become a matter of form, it was for good economic reasons.

But the fact was that gold clauses were not placed in loan agreements and mortgages indiscriminately. Only about fifty-five percent of long-term obligations were subject to gold clauses. ${ }^{115}$ Something other than absence of mind must have led some parties to include gold clauses and others to leave them out. The government itself in its Perry brief recognized the need to compare obligations that included a gold clause with those that did not. ${ }^{116}$

In any case, the inclusion of a gold clause may be expected, on general principles, to have resulted in a lower interest rate since it protected the creditor, albeit quite imperfectly, against inflation.117 The gold clause was, in short, a primitive form of indexation. ${ }^{118}$ The government talked out of both sides of its mouth on this issue. In Bankers Trust it argued that, at least once Roosevelt obtained legislative authorization to devalue the dollar, it would have been impossible for the government to borrow without either including a gold clause or paying "prohibitive rates" of interest. ${ }^{119}$ Yet the gov-

11: See generally Dam, supra note 16. On the greenback period as the origin of widespread use of gold clauses, see M. Fritdman \& A. SchwARTz, supra note 8, at 71 n.78. See also Hanna, Currency Control and Private Property, 33 Colum. L. RBv. 617, 633 n.20 (1933).

11 See Dam, supra note 16, at 374, 410 n.199.

11 See M. Fribdman \& A. Schwartz, supra note 8, at 107 n.27; A. Nussbaum, supra note 19, at 188; Hanna, supra note 112 , at 633 n.20.

115 Brief for the United States and the Reconstruction Finance Corporation at 35 n.14, United States v. Bankers Trust Co., 294 U.S. 240 (1935), reprinted in Kurland \& Casper, supra note 21 , at 259 n.14.

130 See Brief for the United States at 70-75, Perry v. United States, 294 U.S. 330 (1935), reprinted in Kurland \& Casper, supra note 21, at 742-46.

117 See 77 Cong. Rec. 4534 (1933) (remarks of Rep. Luce); Garis, supra note 2, at 220.

118 See generally GoLd, Mongy aND THE LAw (H. Manne \& R. Miller eds. 1975) (discussion of gold clauses and indexation).

110 The government argument was, to be sure, based on the premise that since old issues contained a gold clause, new public issues without one would be at a competitive disadvantage unless offered at "prohibitive rates." See Brief for the United States and the Reconstruction Finance Corporation at 60-61, United States v. Bankers Trust Co., 294 U.S. 240 (1935), reprinted in Kurland \& Casper, supra note 21, at 284-85. But that is exactly the point. When both gold clause and non-gold clause obligations were issued, a debtor would have to pay more if he wanted to avoid indexation of principal and interest implied by a 
ernment argued in Perry that gold clauses were ineffectual: bonds sold at the same price, whether or not they contained a gold clause. ${ }^{120}$ This latter argument seems particularly fallacious, although selective nondisclosure of the underlying data prevents any close analysis of the government's argument. In the absence of information about the face interest rate, the fact that two issues sell at the same price tells us nothing about the effective interest rates. For example, the government attempted to show that two series of treasury bonds with essentially the same maturities, one with a gold clause and one without, sold roughly at par and at almost exactly the same price. Yet the gold clause bonds bore an interest rate of $33 \%$ \% and the non-gold clause bond prices appear to have been derived by averaging prices for bonds ranging in face interest rate from $31 / 4$ to $4 \frac{114}{\%} .{ }^{121}$ The midpoint of that range was $3 \% 4 \%$, well above the $33 \% 8$ face yield for the gold clause bond. The natural conclusion would therefore have been that a higher interest rate was required when a gold clause was not used.

A somewhat more weighty argument for viewing the creditor as receiving a windfall if gold clauses had been enforced after the devaluation of the dollar in January 1934 has to do with the unusual nature of that devaluation. The argument would start from the proposition, noted in the origin of widespread use of gold clauses, ${ }^{122}$ that the prime economic function of gold clauses was to protect the creditor against inflation. Devaluation is usually associated with inflation or, more precisely, with a more rapid rate of inflation than that of other countries. Inflation was not, however, the cause of the 1934 devaluation. Quite the contrary, for, as noted above, prices had fallen rapidly since 1929. Although periods of price declines had been common in American history, the 1929-33 decline had been uncommonly abrupt. ${ }^{123}$ The purpose of the deval-

gold clause. Hence it is fatuous to argue that the gold clause was not bargained for.

130 See the government's argument with respect to two obligations of the Chicago, Burlington and Quincy Railroad, Brief for the United States at 73-74, Perry v. United States, 294 U.S. 330 (1935), reprinted in Kurland \& Casper, supra note 21, at 745-46. Because both the face interest rates and the maturities of the two bonds were substantially different (one maturing 13 years after the other), one cannot evaluate this evidence without knowing the shape of the yield curve throughout this period.

122 See Brief for the United States at 28-29, Perry v. United States, 294 U.S. 330 (1935), reprinted in Kurland \& Casper, supra note 21, at 700-01.

122 See supra notes 111-14 and accompanying text.

${ }^{123}$ For a plotting of the wholesale price index from 1867 to 1960 , see M. FrIEDMaN \& A. Schwartz, supra note 8 , at 678 (Chart 62). As is obvious from that chart, the 1929-33 decline was not as sharp as the 1920-21 decline but it lasted longer. In the nineteenth century, declines were gentler but tended to last much longer. 
uation was not to bring the dollar exchange rate into correspondence with the relative purchasing power of the U.S. and foreign currencies. Instead, Roosevelt sought to generate inflation by forcing the exchange rate out of such correspondence. ${ }^{124}$ This was in part what later critics had in mind when they sought through the Bretton Woods agreement to prevent such "competitive depreciation" of the currency. ${ }^{125}$

Thus, by 1933 holders of obligations that had been outstanding since 1928 or before had already experienced a considerable increase in the purchasing power of interest payments and in the implicit purchasing power of outstanding principal. To enforce the gold clause and thereby award a further increase in nominal dollars in interest and principal must have seemed to be rewarding the creditor twice over. A numerical example may help to explain this point. Assume that a $\$ 1000$ bond was issued bearing a five percent interest rate (fifty dollars per annum) in 1929. Using the wholesale price index as a measure, that fifty dollars per annum would buy one-third more by 1933 ; thus it was worth over sixtyfive dollars in 1929 dollars. After the 1934 devaluation, enforcement of the gold clause would have increased the purchasing power of interest payments to $\$ 110$ in 1929 dollars, an effective yield in real terms of eleven percent on the 1929 investment. ${ }^{126}$ To be sure, the Roosevelt program was inflationary; by the time the Gold Clause Cases were decided in February 1935 wholesale prices had risen thirty-three percent above the 1933 nadir. The case for protecting creditors therefore should have seemed stronger than at the time of the Joint Resolution. But as wholesale prices were still nearly seventeen percent below the 1929 level, ${ }^{127}$ the windfall argument was not entirely baseless.

\section{V}

The Treasury continued to buy gold at the new thirty-five-dol-

124 See supra notes $42-43$ and accompanying text.

125 See K. DAM, supra note 11, at 63-64, 88-92.

128 In 1929 the wholesale price index stood at 95.3 ; in 1933 it was 65.9. BUREAU OF THE Census, U.S. Dep't of Commerce, Historical Statistics of the United States, Colonial Trmes to 1957, at 116 (1960) (Table E 13-24, Wholesale Price Indexes). The effective return Fould actually be higher than $11 \%$, taking into account payment of the principal amount on maturity at $\$ 1690$. The exact effective return would depend on the bond's maturity date.

127 In February 1935 the wholesale price index stood at 79.5, compared with the 1929 annual figure of 95.3. Federal Reserve Statistics, 21 Frd. Ressavs BuLl. 248 (1935). Its lowest point was 59.8 in February 1933. Federal Reserve Statistics, 19 FRD. REsBRVE BuLL. 783 (1933). 
lar per ounce rate. Since this price made gold production here and abroad highly profitable and since the dollar was greatly undervalued as the result of the massive devaluation, gold began flowing into the Treasury coffers. The flow accelerated as fear of Nazi Germany spread in Europe. By 1939 U.S. gold holdings had increased to $\$ 17.6$ billion from $\$ 7.4$ billion in February $1934 . .^{128}$

The U.S. gold purchases cannot be said to have placed the country on a gold standard because those gold inflows did not necessarily determine the money supply. In fact, the Treasury at one point adopted a "sterilization" policy to prevent any expansion of the money supply as a result of these gold inflows. ${ }^{129}$ Still the U.S. policy of buying and selling gold at the official price of thirty-five dollars per ounce at the behest of foreign monetary authorities ${ }^{130}$ became the cornerstone of the Bretton Woods system. Under that system, gold was held by central banks and treasuries as international reserves, and the willingness of the United States, alone among major countries, to buy and sell gold at an official price was a key mechanism (together with intervention by foreign monetary authorities) holding together the set of fixed exchange rates that characterized the international monetary system from World War II until the early 1970 's. ${ }^{131}$

Looking backward from the 1980's it is sometimes thought that because of the commitment to buy and sell gold the United States was on a gold standard during the Bretton Woods period. But it was at best on what Milton Friedman has called a pseudogold standard and not on a real one..$^{132}$ There was no direct relation between U.S. gold holdings and the money supply. ${ }^{13 s}$

128 See Board of Governors of the Federal Reserve System, Banking and Monetary Statistics 536-38 (1943). See generally F. Graham \& C. Whittlesey, Golden AvaLANCHE 3-28, 41-66 (1939).

119 See A Treasury Statement on the Sterilization of Gold (Dec. 22, 1936), reprinted in 5 FDR PAPERs, supra note 1, at 617. See also M. Frimdman \& A. SchwarTz, supra note 8, at 506-11; Bernstein, supra note 25, at 314-16.

${ }^{130}$ See Provisional Regulations Issued Under the Gold Reserve Act of 1934, § § 42, 44, 20 Fed. Reserve Burx. at 82, 88 (1934); Review of the Month, 20 Fed. Reserve Bull. 141 (1934). The price on sale involved a slight charge comparable to the "gold points" under the gold standard.

19s See K. DAM, supra note 11, at 95-98.

193 Friedman, Real and Pseudo Gold Standards, 4 J.L. \& Econ. 66, 74 (1961).

1ss To be sure, there remained a gold cover requirement in U.S. domestic law. Federal Reserve Act, ch. 6, § 16, 38 Stat. 251, 265-266 (1913) (current version codified in relevant part at 12 U.S.C. $\$ 413$ (1976)). The Federal Reserve Act required reserves of $35 \%$ in "gold or lawful money" against Federal Reserve deposits and of $40 \%$ in gold against Federal Reserve notes. This requirement was reduced to a uniform $25 \%$ in gold certificates in 1945 , when the System was approaching the minimums set in 1913. Federal Reserve Act Amend- 
By 1960 the U.S. Treasury was more likely to be on the selling than the buying side of gold transactions. The dollar was at midpoint in a long passage from undervalued status during the "dollar shortage" period just after World War II to the overvalued status that led to the suspension of the gold undertaking in 1971. The Kennedy Administration came to power with the mission of preserving the U.S. gold commitment. The mission required, in its view, policies that would arrest the decline in U.S. gold holdings. ${ }^{134}$ The most immediate threat was perceived to be the tendency of gold to rise above thirty-five dollars per ounce in private markets abroad. (There was, of course, no domestic market except for the tightly controlled market for newly mined gold and for industrial users.) Although the United States sold gold only to foreign monetary authorities, it feared arbitrage by central banks between the private and the official market, resulting in a gold outflow from the United States. ${ }^{185}$

The Kennedy Administration therefore prohibited U.S. citizens from holding gold not just within the United States, as had been the case since 1934, ${ }^{138}$ but anywhere in the world. ${ }^{187}$ The notion was that U.S. citizens were likely to be on the buying side of foreign gold transactions and thereby to drive private gold prices higher. ${ }^{138}$ Extraordinary efforts were made by the U.S. government to avoid foreign purchases in order to relieve balance of payments

ments, Pub. L. No. 79-84, § 1, 59 Stat. 237, 237 (1945) (codified at 12 U.S.C. $\$ \S 248,413-414$ (1976)). In 1965 the requirement was abolished entirely for deposits. See Act of Mar. 3, 1965, Pub. L. No. 89-3, $\S 1,79$ Stat. 5 (current version at 12 U.S.C. $\S 413$ (1976)), and in 1968 it was abolished for notes, see Act of Mar. 18, 1968, Pub. L. No. 90-269, 82 Stat. 50 (current version at 12 U.S.C. \& 391 (1976)).

134 Kennedy "used to tell his advisers that the two things which scared him most were nuclear war and the payments deficit." A. Schlesingre, A Thousand Days 654 (1965). On anxiety over possible foreign gold claims and a foreign exchange crisis, see id. at 651-55 and T. SORENSEN, KENNEDY 406-09 (1965). U.S. gold holdings had fallen from $\$ 22.8$ billion in 1950 to $\$ 17.8$ billion in 1960 and continued to slide to $\$ 14.1$ billion in 1965 and $\$ 11.1$ billion in 1970. IMF, IntrRnational. Financial Statistics 2-3 (1972 Supp.).

$138 \mathrm{~K}$. DAM, supra note 11 , at $137,185-86$.

136 See Provisional Regulations Issued under the Gold Reserve Act of 1934, § 14, 20 Frd. Reserve Burc. 82, 84 (1934) (permitting citizens to hold gold outside the United States); see also supra text accompanying note 64.

137 Exec. Order No. 11,037, 3 C.F.R., 1959-1963 Comp., at 621 (1964). The courts continued to uphold the power to prohibit private ownership of gold against challenges based on the absence of any national emergency justifying such a prohibition. See, e.g., Pike v. United States, 340 F.2d 487 (9th Cir. 1965). See also Holzer, How Americans Lost Their Right To Own Gold-And Became Criminals In The Process, 39 Brooksyn L. Rвv. 517, 546-52 (1973).

138 The United States also fed gold into foreign markets to depress the private gold market price. See K. DAM, supra note 11, at 137-38, 185-86 (discussion of the 1961 Gold Pool). 
pressures on the dollar, with Secretary of Defense Robert McNamara going so far as to adopt a "gold budget" limiting offshore military procurement. ${ }^{139}$ The United States also adopted extensive exchange controls in order to control dollar outflows. ${ }^{140}$

These extensive efforts were to no lasting avail. On August 15, 1971, President Nixon announced that the United States would no longer honor its pledge to buy and sell gold, not just at thirty-five dollars per ounce but at any price whatever. ${ }^{141}$ The U.S. gold window had been closed. ${ }^{142}$ Although the United States later devalued the dollar not simply in terms of other currencies but also in terms of gold, the new official price of thirty-eight dollars (increased in 1973 to $\$ 42.22$ ) had little significance. It was, in the phrase of the time, the price at which the United States did not buy or sell gold. ${ }^{143}$ Thus, even when the private market gold price reached $\$ 875$ in January $1980,{ }^{144}$ U.S. gold holdings continued to be valued at $\$ 42.22$ per ounce without any resulting impact on gold flows or on the U.S. exchange rate.

This very disconnection between the private gold market and the international position of the U.S. dollar had major implications for the dollar. Once the gold window was closed, the need to protect the U.S. gold stock declined. In 1973 the President was given statutory power to abolish the prohibition against private gold holdings. ${ }^{145}$. This sharp reversal was uncontroversial, being supported both by the proponents of floating exchange rates who sought to have gold treated like any other commodity and by those who wanted to return to the gold standard. Since the United States was the only major country to prohibit its citizens from holding gold, even those who wanted to see a return to a Bretton Woods system reluctantly acceded to the logic of repeal. ${ }^{146}$ In August 1974, in the absence of any presidential action under the 1973

180 G. Treverton, The Dollar Drain and American Forces in Germany 8-10, 34-40 (1978); see also Annual Message to the Congress: The Economic Report of the President, 1968-69 PUB. PAPRRs 126, 135 (Feb. 1, 1968) (discussing steps taken to improve U.S. balance of payments); President's News Conference, 1968-69 Pub. Papzrs 1 (Jan. 1, 1968).

${ }^{140}$ See G. Shultz \& K. Dam, Economic Policy Beyond the Headunges 111 (1978).

${ }^{141}$ Address to the Nation Outlining a New Economic Policy: "The Challenge of Peace," 1971 Pub. Papers 886, 888 (Aug. 15, 1971).

14s See W. SAFIRE, Berore the FALL 509-28 (1975) (discussing the background of the decision to close the "gold window").

${ }^{143}$ K. DAM, supra note 11, at 190. See also id. at 193.

14 N.Y. Times, Jan. 22, 1980, at D7, col. 1.

${ }^{145}$ Par Value Modification Act Amendments, Pub. L. No. 93-110, § 3(b), (c), 87 Stat. 352, 352 (1973) (codified in part at 31 U.S.C. $\$ 442$ (1976) and printed in part at 31 U.S.C. $\S$ 443 note (1976)).

146 See, e.g., 119 Cong. REc. 2992-93 (1973) (statement of Sen. Bible). 
statute, the prohibition was lifted by congressional action effective December 31, 1974.147

When the world and the dollar seemed quite unaffected by the resumption of gold trading in the United States and when inflation became an increasingly serious matter, pressure to repeal the 1933 Joint Resolution increased. In 1977 that further step was taken, ${ }^{148}$ but the repeal was made applicable only to "obligations issued on or after the date of enactment of this section."148 The courts therefore rejected attempts by holders of old gold clause obligations to obtain gold or gold value at a time when gold was selling for hundreds of dollars an ounce. ${ }^{160}$

\section{VI}

In October 1980 proponents of a return to the gold standard succeeded in attaching a rider creating a Gold Commission to a statute increasing the U.S. quota in the International Monetary Fund. The Commission was to "conduct a study to assess and make recommendations with regard to the policy of the United States Government concerning the role of gold in domestic and international monetary systems."161 The Commission's report decisively rejected a return to the gold standard. Only three of its seventeen members favored the gold standard. ${ }^{152}$ The majority report,

167 Act of Aug. 14, 1974, Pub. L. No. 93-373, § 2, 88 Stat. 445, 445 (codified at 31 U.S.C. $\S 442$ (1976)). The statute gave the President power to arrest automatic implementation by filing a report but no such report was forthcoming.

${ }^{448}$ Act of Oct. 28, 1977, Pub. L. No. 95-147, § 4(c), 91 Stat. 1227, 1229 (codified as amended at 31 U.S.C. $\S 463$ (1976 \& Supp. V 1981)). A 1935 Joint Resolution, ch. 780, § 2, 49 Stat. 938,939 (1935) (codified at 31 U.S.C. $\$ 773 b$ (1976)) withdrawing U.S. consent to be sued on gold clauses remains in effect.

140 Act of Oct. 28, 1977, Pub. L. No. 95-147, § 4(c), 91 Stat. 1227, 1229 (codified as amended at 31 U.S.C. $\$ 463$ (1976 \& Supp. V 1981)).

${ }^{130}$ Equitable Life Assurance Soc'y v. Grosvenor, 582 F.2d 1279 (6th Cir. 1978), aff'g 426 F. Supp. 67 (W.D. Tenn. 1976), cert. denied, 439 U.S. 1116 (1979); Southern Capital Corp. v. Southern Pac. Co., 568 F.2d 590 (8th Cir.), cert. denied, 436 U.S. 927 (1978); Feldman v. Great N. Ry., 428 F. Supp. 979 (S.D.N.Y. 1977); Gold Bondholders Protective Council v. Atchison, T. \& S. Ry., 649 P.2d 947 (Aleska 1982).

${ }^{151}$ Act of Oct. 7, 1980, Pub. L. No. 96-389, § 10(b), 94 Stat. 1551, 1555 (printed at 31 U.S.C. \& 822a note (Supp. V 1981)).

182 Two members, Lewis Lehrman and Ronald Paul, filed a 300-page minority report to that effect and a third, Arthur Costamagna, gave the minority report a qualified endorsement. See 2 Gold Commission Report, supra note 5, at 7-8. The Commission was composed of three members of the Board of Governors of the Federal Reserve System, two members of the Council of Economic Advisers, and four private citizens drawn from business, finance, or academia, all designated by the Secretary of the Treasury, and six members of Congress drawn from the relevant banking and economic committees and appointed by the Speaker of the House and President of the Senate. See Pub. L. No. 96-389, § 10(a), 94 Stat. 1551, 
having focused on the problem of inflation, came to the conclusion that, "under present circumstances, restoring a gold standard does not appear to be a fruitful method for dealing with the continuing problem of inflation."16s With regard to gold in the international monetary system, the Commission favored not only "no change in the flexible exchange rate system" but also "no change in the usage of gold in the operation of the present exchange rate arrangements."154

The Commission did, however, recommend several actions that could constitute minor steps toward restoration of a gold standard. The primary recommendation of this kind was for "Treasury issue of gold bullion coins of specified weights, and without dollar denomination or legal tender status, to be manufactured from its existing stock of gold and to be sold at a small mark-up over the market value of the gold content."155 Such gold coins could, in the view of some of their advocates, take on monetary characteristics and thus be forerunners of gold coins in a return to a pre-1933 type of gold standard. ${ }^{158}$ They are more likely, however, to be nothing more than vehicles for private investment in gold, like Krugerrands issued by the Republic of South Africa and indeed like gold medallions issued by the U.S. Treasury since $1980 .{ }^{187} \mathrm{It}$ was precisely to prevent newly issued gold "coins" from being purchased for monetary purposes that opponents of a gold standard

1555 (1980) (printed at 31 U.S.C. $\$ 822 a$ note (Supp. V 1981)).

${ }_{15 s} 1$ Gold Commission REPORT, supra note 5, at 17. Some of the members criticized the Gold Commission, one characterizing it as a "runaway" commission because it went well beyond Congress's narrow charge to examine "the role of gold in domestic and international monetary systems," " id. at 1, to analyze inflation and to issue prescriptions, including the monetarist recommendation that "the Congress and the Federal Reserve [should] study the merits of establishing a rule specifying that the growth of the nation's money supply be maintained at a steady rate which insures long-run price stability," id. at 17 . The Commission's principal staff member was Anna J. Schwartz, coauthor of the massive MONETARY History of The UnITED States, supra note 8, with Milton Friedman, the best-known advocate of such a monetary rule.

1341 Gold COMmission REPORT, supra note 5, at 20.

${ }^{168}$ Id. at 9. The report also recommended that sales of the coins be exempt from capital gains and sales taxes. The Commission opposed "issue of Treasury gold-backed notes or bonds." Id. at 10. Such an obligation would be equivalent to a bond containing a gold clause. The case for such an issue would be twofold: the interest cost would presumably be lower than for conventional borrowings because the principal would be indexed to gold, and the issue would be a step toward a greater role for gold. It is interesting that France issued gold securities ("Giscard bonds") in 1973, which because of the rise in the price of gold are now quoted at a considerable multiple of the original issue price. See, e.g., Dare France discard the Giscard?, Economist, July 5, 1980, at 86.

${ }^{158}$ See 1 Gold Commission Report, supra note 5, at 5.

${ }_{167}$ These medallions are issued under the American Arts Gold Medallion Act, Pub. L. No. 95-630, tit. IV, $\S 8402-407,92$ Stat. $3641,3679-80$ (1978). 
successfully resisted the imprinting of any dollar denomination and the according of legal tender status to such coins. ${ }^{158}$

\section{VII}

A return to the gold standard is not imminent. But many of the decisions made by the President and the Congress in 1933 in order to take the United States off the gold standard are no longer in force. Citizens may own gold, even gold in a medallion form that looks much like coin, and post-1977 gold clauses are now fully enforceable. The Gold Clause Cases now apply only to pre-1977 contracts.

The Gold Commission report was in many ways a non-event. The steps it recommended would make little difference. What is important about the report is that, a half century after the departure from the gold standard and at a time when nostalgia for a return to that standard was at a high point, only three out of seventeen votes could be mustered in support of that goal. The fact that, despite the steps backward toward the pre-1933 legal situation, a gold standard is still economically as far away as it was in the Roosevelt years shows that a gold standard requires much more far-reaching changes than those seriously considered thus far. The polity is unwilling to subject the domestic money supply and interest rates to any external and arbitrary rule based on gold holdings and flows.

Nor is there much support for a return to fixed exchange rates based on gold. The volatility in gold's price has diminished its appeal as an anchor for the world's economies and has made it appear practically impossible for the Treasury to commit itself to a fixed price at which the dollar would be convertible into gold. ${ }^{169}$ Nonetheless, the grave problems that have arisen under the post1973 floating exchange rate system have made a fixed exchange rate system appear attractive to many U.S. financial leaders.

If rates of inflation continue to decline around the world, a return to fixed exchange rates may be possible. Gold would be likely to find a role in a fixed exchange rate system, especially as such a large proportion of national holdings of international reserves are in gold. ${ }^{160}$ Under such circumstances, a return to a

16s See 1 Gold Commission Report, supra note 5, at 7-9.

180 For a discussion of this issue, see $K$. DAM, supra note 11, at 338-41.

${ }^{200}$ The amended Articles of Agreement of the International Monetary Fund have largely phased gold out of the formal international monetary system. See K. DAM, supra note 11, at 269-75. But gold plays a major role in the sense that $49 \%$ of international 
full-scale gold standard might come to be seen as a viable policy option by a much wider range of monetary experts and elected officials. On the other hand, the necessary precondition for consideration of a return to the gold standard, a long-term subsidence in inflation both here and abroad, would itself undermine much of the political case for such a return. The case for a gold standard is most appealing when inflation is rampant but, paradoxically, rapid inflation makes a gold standard impracticable. 